\title{
Analysis of Livestock Farmers Willingness to Pay for Agricultural Extension Services in South East Nigeria
}

\author{
${ }^{1}$ Onoh, P. A., ${ }^{2}$ Omeire, C. O., ${ }^{1}$ Echetama, J. A., ${ }^{1}$ Ukpongson, M. A., ${ }^{1}$ Ugwoke, \\ F. O., ${ }^{1}$ Ejiogu-Okereke, E. N., ${ }^{1}$ Onoh, A. L. and ${ }^{1}$ Agomuo, C. I. \\ ${ }^{I}$ Federal University of Technology Owerri, Imo state ${ }^{2}$ Micheal Okpara University of Agriculture, Umudike, \\ Abia state
}

\begin{abstract}
The study analyzed livestock farmers' willingness to pay for extension services in South East Nigeria. Data were collected with structured and validated questionnaire from 360 randomly selected farmers .Data were analyzed using descriptive statistics and a 4-point likert type scale. Results showed that only $35.30 \%$ of the farmers were willing to pay for agricultural extension services. The results also showed that farmers were willing to pay for extension services in home stead fish production, improved productions in poultry and piggery, but were not willing to pay for techniques in animal feed formulation and in sheep and goat productions. Farmers agreed that paying for extension services would make extension more need and problem centered and would increase the commitment of extension staff. This study concludes that both private and public extension services should be encouraged to exist side by side.
\end{abstract}

Keywords: Agricultural extension, Livestock Farmers, Questionnaire, South East Nigeria, Willingness to pay.

\section{Introduction}

Agricultural extension aims at providing farmers with the necessary education, skill and technical information to enable them take effective farm management decisions to enhance their daily practices .An effective extension service is therefore an essential factor for the accelerated development of agriculture in developing economies. Such a service must provide adequate linkage between the research system and the farmers with a view to facilitating the farmers adoption of improved practices and skills. Almost all the services provided by public sector extension have been traditionally free. Demanding fees for providing any type of services has been something new to the public extension service. Extension is considered as some sort of public education, and making it available at the field level has been the strategies to make farmers adopt the promoted technologies [1].Agricultural research and extension systems in developing countries are confronted with the challenge of providing adequate educational and technical extension programmes for all groups of farmers due to a significant decline of government expenditure in national budgets [2].The international donor community has emphasized the importance of recognizing the provision of agricultural technologies in developing countries through restructuring national agricultural research and extension services, supporting the promotion of agricultural services for markets, and promoting consumer-oriented agribusiness systems.

The government established the Agricultural Development Projects (ADPs) with full legislative backing as well as strong and reliable support. [3] felt that privatization and commercialization will reduce the operational horizon of the ADPs. The new owners may concentrate on or emphasize only high net worth extension clientele. Invariably, the resource poor small -scale peasant producers who form the bulk of our farming population may become more disadvantaged. They may become marginalized because of their poverty since extension services may be priced out of their reach. He further stated that business entrepreneurs invest in ventures of high profit, and that agricultural extension is not known to be of high net return (in cash terms) to investment. Will an investor inject the much needed capital into the extension business for charity? Privatization of agricultural extension is the bitter pill that Nigeria must swallow. The question that arises at this juncture relates to the survival of the rural farming populace who patronize agricultural goods and services in the context of a privatized and commercialized agricultural extension delivery system.

Willingness to pay for agricultural services is influenced by a number of paradigms including the innovation -diffusion model [4], economic constraints model [5] and adopters' perception model [6]. Innovation -diffusion model may include factors the respondents may have been exposed to in relation to the extension services being targeted including duration, regularity of services, quality of the services and effectiveness of its delivery. [7] investigated Ugandan farmers willingness to pay for different agricultural services .The results showed that farmers with access to information on proposed agricultural services were less willing to pay for it .Also access to extension services tended to reduce farmers willingness to pay. [8] in a study on constraints to privatization and commercialization of agricultural extension services as perceived by extension professionals and farmers in Delta State of Nigeria showed the following as constraints to farmers willingness to pay for 
extension services; fear of job insecurity among extension staff; lack of farmers interest in extension programmes ; high risk and uncertainty in personnel ; tendency to focus more attention on large scale farmers amongst others.

Economic importance of animal husbandry enterprise and respondents socio-economic characteristics influenced livestock producers demand for private veterinary services including clinical services, artificial insemination, vaccination and health services in the high potential agricultural areas of Kenya [9]. Livestock production is a source of employment and livelihood in Nigerian agriculture. A large percentage of the rural people satisfy their subsistence needs through livestock production which involves the rearing and marketing of livestock. This class of animals includes cattle, sheep, goats, pigs, and poultry. According to [10] Nigeria's livestock resources include 13,885,813 cattle, 34,453,724 goats, 22,092,602 sheep, 3,406,381 pigs and $104,247,960$ poultry. Traditionally managed stock is over $85 \%$ for all species while commercially managed is only significant for poultry at $13.8 \%$ and to a lesser extent for pigs at $3.24 \%$. [11] , stated that the most significant shortcomings of public agricultural extension in general have been unresponsiveness to the variation in farmers needs, lack of ownership by intended beneficiaries, limitation in the quality of field and technical staff and unstable policy and political support. He stated that the old Anyigba Agricultural Development Project was denied needed political support by the then Benue State Government which led to its atrophy. [12] observed that governments' dwindling development budgets and extremely poor progress in raising economic and social well-being of the populace through public extension have led to calls for private sector involvement in the provision of extension services .According to [13] , public sector extension is facing criticism and is confronted with a number of possibilities for change because of its lack of efficiency. .

\section{Materials and methods}

The area of study is southeast Nigeria. Southeast Nigeria is made up of five states: Abia, Anambra, Ebonyi, Enugu and Imo. It has a total population of 16.38 million people with about 75 percent or 8.78 million people living in rural areas, of which about 49.38 percent are women [14] .The occupation of the people is basically farming, combined mainly with non-farm activities in varying degrees. The people are mainly of Igbo tribe of Nigeria. Dominant arable crops of the area include rice, yam, cassava, maize, cocoyam, and vegetables. Backyard poultry keeping and small ruminant animal production dominate the livestock industry in the area while muturu cattle rearing are an exception, and limited mainly to parts of Enugu and Ebonyi States. A multistage random sampling was adopted for this study. In the first stage, three states of Ebonyi, Enugu and Imo were randomly selected from the five states of southeast Nigeria. This was followed by random selection of three local government areas (LGA) from each state .This gave a total of nine local government areas for the study. They include; Ohaozara, Abakaliki, Ishielu ,Awgu, Nsukka ,Udi,Onuimo, Owerri North and Ideato South. This was followed by random selection of two communities from each LGA to give a total of eighteen (18) communities for the study. They include; Okposi, Uburu ,Nkaliki, Agbaja, Ezillo, Nkalagu, Agwu, Mgbowo, Opi, Edem Ani, Amokwe, Ngwo, Okwelle, Okwe, Emekuku, Orji, Dikenafai, and Isiekenisi. Lastly twenty two (22) farmers who had had contact with extension agents were sampled to give a total of three hundred and ninety six (396) farmers. Three hundred and sixty (360) questionnaires, which represented ninety one percent $(91 \%)$ of the questionnaire administered to the respondents were retrieved and used for further analysis. Simple percentages and 4-point Likert type scale were used for the analysis of field data.

A 4- point type likert scale was employed to determine perceived willingness to pay for extension services by farmers of southeast Nigeria. Respondents were categorized into two patterns depending on their mean score. The mean scores above 2.5 were categorized as positive, while those below it as negative. The scores assigned to the categories are as follows;

Strongly unwilling $=1$, Unwilling $=2$, willing $=3$, strongly willing $=4$

The extent extension services are currently paid for by the farmers, the scores assigned to the categories are as follows; Very great extent $=4$, Great extent $=3$, Low extent $=2$ and Not at all $=1$. For perceived benefits for paying for extension services, the scores assigned to the categories were as follows; Strongly agree $=4$ , Agree $=3$, Disagree $=2$ and Strongly disagree $=1$

\section{Results And Discussion}

\section{Distribution of Farmers by their Willingness to Pay for Extension Services.}

Experiences have shown that inefficiencies are unavoidable if a service such as agricultural extension continues to be provided free of charge to farmers and almost finally run by governments .It therefore follows that farmers must pay for the service they get from extension services for them to appreciate the worth of the service, [15] Table 1 shows the percentage distribution of the farmers according to their Willingness to Pay for Extension Services. The result showed that $35.3 \%$ of the farmers were willing to pay for extension services, while $67.7 \%$ were not willing to pay. Where extension services have been provided free of charge, it could be difficult to establish the latent commercial demand for agricultural extension information. 


\section{Farmers' willingness to pay for improved livestock practices}

The results showed that farmers were willing to pay for extension service on home stead fish production, with 2.7 mean value and standard deviation of 0.88 ,improved production in poultry with mean value of 2.7 and standard deviation of 0.88 , and in improved techniques in piggery production with mean value of 2.6 and standard deviation of 0.96 . However, the mean value of other services where farmers responses were sort were below the cut off mean of 2.5, indicating that farmers were not willing to pay for them. They included; Animal feed production and improved technique in sheep and goat production. This agrees with [16] which stated that poultry and cattle had a statistically significant positive effect on willingness to pay for extension services in Zimbabwe. This unwillingness to pay may also be explained by possible initial high capital requirement for their establishment.

\section{The extent livestock farmers are currently paying for extension services}

The result presented in table 3 shows to what extent farmers in the area are currently paying for extension services. The results show that farmers were currently paying for extension services in home stead fish production with mean value of 3.1 and standard deviation of 0.8 , in improved poultry production with mean value of 2.9 and standard deviation of 0.39 , and animal feed production with mean value of 2.8 and standard deviation of 1.17. They were however not paying for most of the other extension services; like, improved technique in sheep and goat production and improved technique in rabbit production. The reasons for farmers not paying for the above extension services could be because, they were able to handle the technologies easily, or that the government free extension service provided them with enough information to take care for such needs or problems arising from them, or still they may find such technologies inappropriate. On the other hand, farmers might have found the extension services in such technologies they were willing to pay for complicated to handle and were willing to pay for their services, or still, may be the profit margin from them was high, thus warranting the payment.

Results presented in table 4 show the distribution of farmers on their perceived benefits for paying for extension services. Farmers felt that paying for extension services would encourage their involvement in programmer planning process with a mean value of 3.0 and standard deviation of 0.91 , it is obvious that farmers' involvement in programmer planning process would aid faster acceptability and adoption of innovations amongst them. They also felt it would aid efficient delivery of extension services with a mean value of 2.9 and standard deviation of 1.06. Farmers agreed that paying for extension services would make extension to become more need/problem centered with a mean value of 2.8 and standard deviation of 0.99 . They agreed also that paying would expose incompetent extension staff with a mean value of 2.8 and standard deviation of 0.96. This would put extension staff on their toes and cause them to be more committed to their jobs. Farmers agreed that paying would aid better operational linkage between extension, research and other relevant agencies with a mean value of 2.6 and standard deviation of 1.04 . They also belief that paying for extension services would increase the commitment of extension staff with a mean value of 2.7 and standard deviation of 1.10.Farmers however, did not belief that paying for extension services would better equip them to handle home and farm problems, better appreciate the need for extension services and also that paying would increase their production capacity.

\section{Conclusion and Recommendations}

The study clearly showed that the proportion of farmers willing to pay for extension services was low. The results also show that farmers were willing to pay for extension services in home stead fish production, improved productions in poultry and piggery, but were not willing to pay for techniques in animal feed formulation and in sheep and goat productions. Farmers agreed that paying for extension services would make extension more need/problem centered and increase the commitment of extension staff. As a way of improving farmers' willingness to pay for extension services, this study recommends the following;. Private extension agencies need to get involved as a supplement, those who could afford their services should patronize them. As a way of improving farmers' willingness to pay for extension services, private extension personnel should be very competent and dedicated

Table 1: Distribution of Farmers by their Willingness to Pay for Extension Services.

\begin{tabular}{lll}
\hline Pay & Frequency & Percentage \\
\hline Yes & 127 & 35.3 \\
No & 233 & 67.7 \\
Total & 360 & 100
\end{tabular}

Source: Field survey, (2013). 
Table 2: Farmers' Willingness to Pay for Improved Livestock Practices.

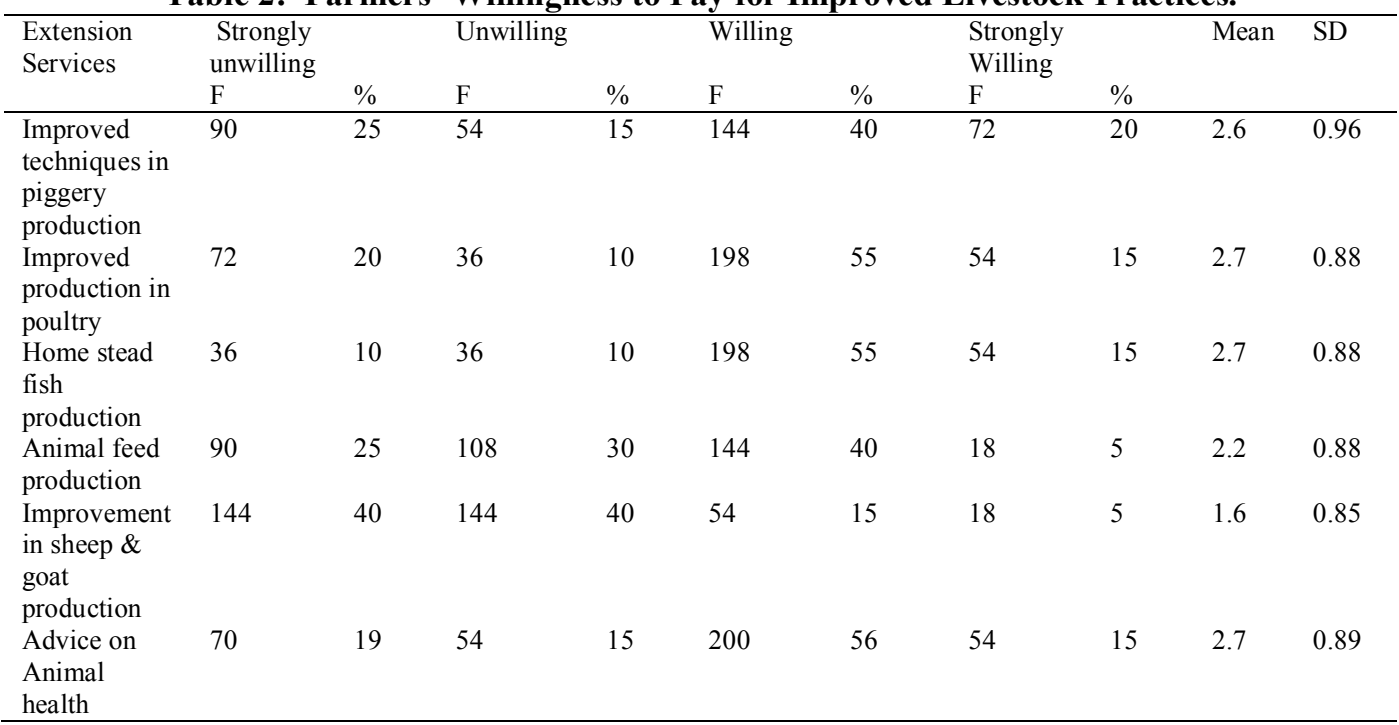

Willing to Pay (mean $\geq 2.5$ ) Source:Field Survey 2013

Table 3: The Extent Livestock Extension Services are currently paid for

\begin{tabular}{|c|c|c|c|c|c|c|c|c|c|c|}
\hline $\begin{array}{l}\text { Extension } \\
\text { Services Paid } \\
\text { For }\end{array}$ & $\begin{array}{l}\text { Very } \\
\text { Great } \\
\text { Extent } \\
\text { F }\end{array}$ & $\%$ & $\begin{array}{l}\text { Great } \\
\text { Extent }\end{array}$ & $\%$ & $\begin{array}{l}\text { Low } \\
\text { Extent }\end{array}$ & $\%$ & $\begin{array}{l}\text { Not } \\
\text { All }\end{array}$ & $\%$ & Mean & SD \\
\hline $\begin{array}{l}\text { Improved } \\
\text { techniques in } \\
\text { piggery } \\
\text { production }\end{array}$ & 36 & 10 & 72 & 20 & 144 & 40 & 108 & 30 & 2.1 & 0.94 \\
\hline $\begin{array}{l}\text { Improved } \\
\text { production in } \\
\text { poultry }\end{array}$ & 106 & 29.4 & 135 & 37.5 & 82 & 22 & 37 & 10.3 & 2.9 & 0.39 \\
\hline $\begin{array}{l}\text { Home stead } \\
\text { fish } \\
\text { production }\end{array}$ & 108 & 30 & 180 & 50 & 54 & 15 & 18 & 5 & 3.1 & 0.81 \\
\hline $\begin{array}{l}\text { Animal feed } \\
\text { production }\end{array}$ & 144 & 40 & 72 & 20 & 72 & 20 & 72 & 20 & 2.8 & 1.17 \\
\hline $\begin{array}{l}\text { Improvement } \\
\text { in sheep \& } \\
\text { goat } \\
\text { production }\end{array}$ & 0 & 0 & 0 & 0 & 120 & 33 & 240 & 67 & 1.0 & 0.58 \\
\hline $\begin{array}{l}\text { Advice on } \\
\text { Animal } \\
\text { health }\end{array}$ & 130 & 36.10 & 110 & 30.56 & 80 & 22.22 & 40 & 11.11 & 2.8 & 0.65 \\
\hline $\begin{array}{l}\text { Improved } \\
\text { technique in } \\
\text { rabbit } \\
\text { production }\end{array}$ & 0 & 0 & 0 & 0 & 90 & 25 & 270 & 75 & 1.3 & 0.44 \\
\hline
\end{tabular}

Willing to Pay (mean $\geq 2.5$ )Source:Field Survey :2013 
Table 4: Distribution of Farmers on their Perceived Benefits for paying for extension service

\begin{tabular}{|c|c|c|c|c|c|c|c|c|c|c|}
\hline Perceived Benefits & $\begin{array}{l}\text { Strongly } \\
\text { agree }\end{array}$ & Agr & & & $\mathrm{Di}$ & igree & Stron & y dise & & \\
\hline & $\mathrm{F}$ & $\%$ & $\mathrm{~F}$ & $\%$ & $\mathrm{~F}$ & $\%$ & $\mathrm{~F}$ & $\%$ & $\begin{array}{c}\text { Mea } \\
\mathrm{n}\end{array}$ & S.D \\
\hline $\begin{array}{l}\text { Efficient } \\
\text { delivery of } \\
\text { extension } \\
\text { services to } \\
\text { farmers }\end{array}$ & 130 & $\begin{array}{c}36 . \\
1\end{array}$ & 100 & $\begin{array}{c}2.7 \\
8\end{array}$ & 80 & 22.2 & 50 & $\begin{array}{c}13 . \\
9\end{array}$ & 2.9 & 1.06 \\
\hline $\begin{array}{l}\text { Better } \\
\text { commitment of } \\
\text { extension } \\
\text { agents to their } \\
\text { work }\end{array}$ & 120 & $\begin{array}{c}33 . \\
3\end{array}$ & 80 & $\begin{array}{c}22 . \\
2\end{array}$ & 100 & 27.8 & 60 & $\begin{array}{c}16 . \\
7\end{array}$ & 2.7 & 1.10 \\
\hline $\begin{array}{l}\text { Increased } \\
\text { production by } \\
\text { farmers }\end{array}$ & 60 & $\begin{array}{c}16 . \\
7\end{array}$ & 80 & $\begin{array}{c}22 . \\
2\end{array}$ & 130 & 361 & 90 & 25 & 2.3 & 1.02 \\
\hline $\begin{array}{l}\text { Better } \\
\text { appreciation of } \\
\text { the need for } \\
\text { extension } \\
\text { service by } \\
\text { farmers }\end{array}$ & 50 & $\begin{array}{c}13 . \\
9\end{array}$ & 70 & $\begin{array}{c}19 . \\
4\end{array}$ & 160 & 44.4 & 80 & $\begin{array}{c}22 . \\
2\end{array}$ & 2.3 & 0.95 \\
\hline $\begin{array}{l}\text { Farmers are } \\
\text { better equipped } \\
\text { to handle farm } \\
\text { and home } \\
\text { problems }\end{array}$ & 40 & $\begin{array}{c}11 . \\
1\end{array}$ & 90 & 25 & 100 & 27.8 & 130 & $\begin{array}{c}36 . \\
1\end{array}$ & 2.1 & 1.02 \\
\hline $\begin{array}{l}\text { Ex1tension } \\
\text { service will } \\
\text { become more } \\
\text { need/problem } \\
\text { centered }\end{array}$ & 1.06 & $\begin{array}{c}29 \\
4\end{array}$ & 130 & $\begin{array}{c}36 . \\
1\end{array}$ & 80 & 22.2 & 44 & $\begin{array}{c}12 . \\
2\end{array}$ & 2.8 & 0.99 \\
\hline $\begin{array}{l}\text { Extension agents } \\
\text { will become } \\
\text { better trained }\end{array}$ & 100 & $\begin{array}{c}27 \\
8\end{array}$ & 120 & $\begin{array}{c}33 \\
3\end{array}$ & 90 & 25 & 50 & $\begin{array}{c}13 . \\
9\end{array}$ & 2.8 & 1.01 \\
\hline $\begin{array}{l}\text { Encourages the } \\
\text { involvement of } \\
\text { farmers in } \\
\text { programme } \\
\text { planning process }\end{array}$ & 120 & $\begin{array}{c}33 . \\
3\end{array}$ & 136 & $\begin{array}{c}37 \\
8\end{array}$ & 80 & 22.2 & 24 & 6.7 & 3.0 & 0.91 \\
\hline $\begin{array}{l}\text { Better } \\
\text { operational } \\
\text { linkage between } \\
\text { extension } \\
\text { research, and } \\
\text { relevant } \\
\text { agencies }\end{array}$ & 90 & 25 & 108 & 30 & 100 & 27.8 & 62 & $\begin{array}{c}17 . \\
2\end{array}$ & 2.6 & 1.04 \\
\hline $\begin{array}{l}\text { Incompetent } \\
\text { extension agents } \\
\text { will be expose }\end{array}$ & 100 & $\begin{array}{c}27 \\
8\end{array}$ & 135 & $\begin{array}{c}37 . \\
5\end{array}$ & 85 & 23.6 & 40 & 1.1 & `2.8 & 0.96 \\
\hline
\end{tabular}

Scale: strongly agree $=4$, Agree $=3$, Disagree $=2$, Strongly disagree $=1$ Source: Field survey, (2013). 


\section{Reference}

[1]. Wolf. S. A. (Ed). 1998. Privatization of information and Agricultural Industrialization: BocaRaton: FL: CRC Press.

[2]. Swanson B. E. 2008. Global review of good agricultural extension and advisory service practices. Food and Agriculture Organization of the United Nations, Rome.

[3]. Agumagu, A. C. 2001. Privatization, commercialization and sustainable Agricultural extension in Nigeria. Proceeding of the seventh Annual National conference of Agricultural Extension Society of Nigeria PP $113-118$.

[4]. Mitei, R. 2001. Improving Extension Systems in Tropical Agriculture. Washington, D. C: The World Bank

[5]. Pitt, M., and G. Sumodiningrat. 1991.”Risk, Schooling and the Choice of Seed Technology in Developing Countries: A Meta-profit Function Approach," Internationational Economic Review,32:(2)457-473

[6]. Adesina, A.A. and Baidu-Forson, J.,1995. Farmers' perception and adoption on new agricultural technology: evidence from analysis in Burkina Faso and Guinea, West Africa. Agricultural Economics 13, 1-9

[7]. Faye ,I., and K. Deininger 2005.Do New Delivery Systems Improve Extension Access? Evidence from Rural Uganda . Paper presented at the American Agricultural Economics Association Annual Meeting, July 24-27, Providence, RI, US.

[8]. Oladele, O. I. ( 2008): Factors determining farmers willingness to pay for extension services in Oyo State, Nigeria. Agricultura Tropica Et Subtropica 41: (4)165- 169

[9]. Tambi, N. E., Mukhebi W. A., Maina, W.O and Solomon ,H.M.1998. Probit analysis of livestock producers' demand for private veterinary services in the high potential agricultural areas of Kenya. Agricultural Systems 59:163-176

[10]. Tewe O O 1997 Sustainable and Development: "Paradigms from Nigeria's livestock industry". InauguralLecture1996-1997. Polygraphic Ventures Limited. pp1-6

[11]. Idachaba, F. S. (2005): Agricultural and Rural Development in Nigeria. The policy perspective. A text of convocation Lecture Delivered at K.S.U. Anyigba on 11-march, 2005.pp 3 \&

[12]. Okoro, B.O; Chukwu, G.O.; Onumadu T.; Okoye, B.C. (2006). Sustaining

[13]. AgriculturalExtension through informal private sector Participation in Abia State. In G.N.Asumugha, A.O. Olojede, J.G. Ikeorgu, A.O. Ano and U. Herbert (eds), Repositioning Agriculture for Sustainable Millennium Development Goals inNigeria. Proceedings of the 40th Annual Conference of the Agricultural Society ofNigeria (ASN), held at National Root Crops Research institute, Umudike, AbiaState, Nigeria. October 16th - 20th, p.

[14]. Rivera, W. M. and Cary, J. W. (1997): Privatizing Agricultural Extension. A reference Manual, FAO, United Nations, Rome.

[15]. National Population Census, 2007. Federal Government Printer Lagos Nigeria

[16]. Jibowo, A. A.2001. Strengthening and survival of the Agricultural Extension Enterprises; the issue of Privatization and Commercialization. Proceeding of seventh Annual National Conference of Agricultural Extension Society of Nigeria PP.1 - 5

[17]. Foti, R., Nyakudya, I. Moyo, M., Chikuvire, J. and Mlambo, N. 2007. Determinants of farmers Demand for fee-for-service Extension in Zimbabwe. Journal of International Agricultural \& Extension Education. 